CLINICAL STUDY

\title{
Molecular and functional properties of densely and sparsely granulated GH-producing pituitary adenomas
}

\author{
Bernhard Mayr $^{1}$, Rolf Buslei ${ }^{2}$, Marily Theodoropoulou ${ }^{3}$, Günter K Stalla ${ }^{3}$, Michael Buchfelder ${ }^{4}$ and Christof Schöfl ${ }^{1}$ \\ ${ }^{1}$ Division of Endocrinology and Diabetes, Department of Medicine I and ${ }^{2}$ Department of Neuropathology, Friedrich-Alexander University \\ Erlangen-Nuremberg, Ulmenweg 18, 91054 Erlangen, Germany, ${ }^{3}$ Department of Endocrinology, Max Planck Institute of Psychiatry, Munich, Germany \\ and ${ }^{4}$ Department of Neurosurgery, Friedrich-Alexander University Erlangen-Nuremberg, Ulmenweg 18, 91054 Erlangen, Germany \\ (Correspondence should be addressed to C Schöfl; Email: christof.schoefl@uk-erlangen.de)
}

\begin{abstract}
Objective: GH-producing pituitary adenomas display two distinct morphological patterns of cytoplasmic GH-containing secretory granules, namely the densely and sparsely granulated somatotroph adenoma subtype. It is unknown whether these morphological variants reflect distinct pathophysiological entities at the molecular level.

Methods: In $28 \mathrm{GH}$-producing adenoma tissues from a consecutive set of patients undergoing pituitary surgery for acromegaly, we studied the GH granulation pattern, the expression of somatostatin receptor subtypes (SSTR) as well as the calcium, cAMP and ZAC1 pathways in primary adenoma cell cultures.

Results: The expression of GSP oncogene was similar between densely and sparsely granulated somatotroph adenoma cells. There were no differences in the calcium, cAMP and ZAC1 pathways as well as in their regulation by SSTR agonists. SSTR2 was exclusively expressed in densely but not in sparsely granulated tumours (membrane expression 86 vs $0 \%$; cytoplasmic expression 67 vs $0 \%$ ). By contrast, expression of SSTR 5 was only found in sparsely but not in densely granulated somatotroph adenomas (membrane expression 29 vs 0\%; cytoplasmic expression 57 vs 0\%).

Conclusions: Our results indicate that different granulation patterns in GH-producing adenomas do not reflect differences in pathways and factors pivotal for somatotroph differentiation and function. In vitro, the vast majority of both densely and sparsely granulated tumour cells were responsive to SSTR activation at the molecular level. Sparsely granulated adenomas lacking SSTR2, but expressing SSTR5, might be responsive to novel SSTR agonists with increased affinity to SSTR5.
\end{abstract}

European Journal of Endocrinology 169 391-400

\section{Introduction}

The diagnosis and classification of benign and malignant neoplasms have been traditionally based on histo- and cytomorphological as well as immunohistochemical criteria. Over the last decades, however, the molecular characterisation of tumour cells has tremendously enhanced our understanding of tumour pathogenesis. This often led to reclassification of tumours into new entities and subtypes based on specific molecular characteristics and to the identification of novel targets for therapeutic intervention.

In GH-secreting pituitary adenomas, a number of molecular changes have been identified, often through analyses of familial tumour syndromes (reviewed in $(1,2,3))$. Mutations of the GNAS1 (GNAS) gene, called GSP mutations, cause McCune-Albright syndrome and also frequently occur in sporadic GH-secreting adenomas, but despite elevated cAMP levels (4), this does not lead to a distinct pathological or clinical phenotype. Menin mutations are responsible for multiple endocrine neoplasia type I and mutations of the regulatory subunit type 1A of protein kinase A (PRKAR1A) cause Carney complex, but both alterations do not seem to play a role in the development of sporadic adenomas. Recently, mutations in the aryl hydrocarbon receptor-interacting protein (AIP) gene have been found to be one cause of familial isolated pituitary adenoma (5), but AIP mutations in sporadic adenomas appear to be very rare (6). The identification of these molecular alterations, however, did not lead to a clinically relevant subclassification of sporadic GH-producing pituitary adenomas so far.

According to electron microscopy studies, GH-secreting adenomas can be divided into two distinct variants reflecting different patterns of GH-containing secretory granules. The densely granulated subtype is characterised by a high number of large GH-containing secretory granules resembling non-tumorous somatotrophs. In contrast, the sparsely granulated counterpart shows only sparse and small secretory granules. The latter can be easily recognised by the presence 
of juxtanuclear aggregates of intermediate filaments, namely fibrous bodies, showing a distinct immunohistochemical staining pattern using antibodies against cytokeratins $(7,8)$. Recent findings suggest that these phenotypes could be associated with specific molecular characteristics as patients harbouring densely granulated somatotroph adenomas appear to respond better to medical treatment with somatostatin analogues (SSA) than those with the sparsely granulated tumours $(9,10,11,12,13)$.

The physiology of normal GH-secreting pituitary cells is predominantly regulated by the $\mathrm{GH}$ secretagogues GH-releasing hormone (GHRH) and ghrelin as well as by somatostatin, which inhibits GH secretion. GHRH activates the cAMP signalling pathway, which is crucial for growth and differentiation of somatotroph cells and regulates the synthesis and secretion of GH $(14,15)$. Inappropriate activation of the cAMP signalling pathway by activating GSP mutations is one cause for the development of $\mathrm{GH}$-secreting adenomas, which exemplifies the pivotal role of this signalling pathway for somatotroph regulation $(4,15)$. Ghrelin, in its n-octanoylated or n-decanoylated form, binds to the GH secretagogue receptor 1a isoform (GHS-R1a), which couples to $\mathrm{Gq}$ and activates the $\mathrm{Ca}^{2+}$-phosphatidylinositol signalling pathway leading to a rise in cytosolic free calcium $\left(\left[\mathrm{Ca}^{2+}\right]_{\mathrm{i}}\right)(16,17)$. GHRH through activation of the cAMP pathway and regulation of voltage-sensitive $\mathrm{Ca}^{2+}$ influx also causes an increase in $\left[\mathrm{Ca}^{2+}\right]_{\mathrm{i}}(18,19)$, which is the trigger for $\mathrm{GH}$ secretion via the synaptotagmin-mediated exocytosis of GH-containing secretory granules $(16,20,21,22)$. Somatostatin, through activation of the somatostatin receptor (SSTR), suppresses both cAMP and cytosolic calcium signalling, thereby inhibiting $\mathrm{GH}$ secretion and proliferation $(23,24,25)$. Furthermore, in rat somatotroph GH3 cells, analogues of somatostatin enhance the expression of the transcription factor Zac1 (Plag11), which negatively regulates somatotroph growth and function (26). ZAC1 has been suggested as one pathophysiological factor in the development of GH-secreting adenomas as its expression is decreased in pituitary adenomas compared with normal pituitary tissue $(27,28)$.

To investigate whether densely and sparsely granulated GH-secreting pituitary adenomas exhibit distinct molecular and functional characteristics, we studied the immunohistochemical pan-cytokeratin staining pattern, the expression of SSTR subtypes, GSP mutations and ZAC1 as well as the effects of SSTR activation on cytosolic calcium, cAMP and ZAC1 signalling pathways. This was studied in a series of adenoma tissues from consecutive patients undergoing pituitary surgery for acromegaly at a single institution. The characterisation of distinct molecular characteristics of GH-producing adenomas could identify novel drug targets as well as facilitate individualised algorithms for the treatment of patients with acromegaly.

\section{Subjects and methods}

\section{Tissue samples}

Seventy-three consecutive patients underwent transsphenoidal surgery for acromegaly from April 2008 to November 2009 in the Department for Neurosurgery of the University Hospital Erlangen, Germany. Adenoma tissue was obtained from 45 patients who gave their informed consent. Ten of the 45 samples had to be excluded from further experimental analyses because the tissue preparation did not yield sufficient GH-secreting adenoma cells or the primary cell culture contained fibroblasts. The diagnosis was verified in each patient by immunohistochemical staining for pituitary hormones and by a review of the medical history. Seven of the 35 patients had received SSA or radiotherapy in the past and were excluded from further analyses. The mean age of the final cohort of 28 patients was 46.9 years \pm 10.1 (s.D.); 15 patients were female, seven had a microadenoma and 21 patients had a macroadenoma. None of the patients had a family history of pituitary adenoma. Four patients had received dopamine agonist before surgery (Supplementary Table 1, see section on supplementary data given at the end of this article). Only six of 28 patients received medical therapy after surgery for persistent hormone excess; the response to SSA treatment in these patients is shown in Supplementary Table 2. Five normal anterior pituitary tissue samples were obtained during pituitary surgery performed for non-hormone-secreting adenomas and 14 normal anterior pituitaries were obtained during autopsy. All normal pituitaries were examined by tissue staining to ensure the absence of any pathological tissue.

\section{Immunohistochemistry}

Four micrometer thin sections were prepared from formalin-fixed paraffin-embedded tissue and developed using the 3,3'-diaminobenzidine (DAB) method as described previously (29). Evaluation of immunohistochemistry staining was performed by a neuropathologist $(\mathrm{R} B)$ unaware of the experimental results. For evaluation of the pan-cytokeratin expression pattern and detection of fibrous bodies (sparsely granulated somatotroph adenomas), we used the MAB IOPath ${ }^{+}$ Cytokeratin-Large-Spectrum (clone KL1; dilution 1:40; Immunotech, Marseille, France). According to the WHO classification and published studies, adenomas with a mixed appearance were classified as densely granulated adenomas (8). The monoclonal mouse antibody for SSTR2 (clone \#402038) was purchased from R\&D Systems, Wiesbaden, Germany (30). The mouse MABs for SSTR1, 3, 4 and 5 were provided by Novartis, and their specificity has recently been described in detail (31). The SSTR 5 antibody was raised against amino acids 350-363 at the very C-terminus of the human SSTR 5 (31) and therefore does not recognise recently 
described truncated SSTR5 variants that arise from alternative splicing at the C-terminus $(32,33)$.

Each section was graded for the percentage of stained adenoma cells (no staining, <10, 10-50, 50-90 and $>90 \%$ ). Intensity of staining was graded in comparison to control samples from normal pituitary tissue (for SSTR1, 2, 3 and 5) and to pancreas tissue (SSTR4) (no staining, $(+)$ barely detectable, + weakly positive below the intensity of control sample, ++ same intensity as controls, +++ stronger than controls). The absolute intensity was clearly higher for membrane than for cytoplasmic staining $(30,31)$. Samples were scored positive when they showed a ++ or +++ staining in more than $50 \%$ of tumour cells as described elsewhere (34). Both membrane and cytoplasmic stainings were evaluated because membrane staining has been observed only rarely for SSTR 1,3 and 5 while cytoplasmic staining for these subtypes was common in different tissues $(35,36,37,38)$.

\section{Primary culture of pituitary adenoma cells}

Adenoma tissue was minced with a scalpel suspended in DMEM and treated with collagenase $A$ at a final concentration of $1 \mathrm{mg} / \mathrm{ml}$ for $1 \mathrm{~h}$ at $37^{\circ} \mathrm{C}$. Undissociated tissue was removed, cells were collected by centrifugation, washed twice and resuspended in DMEM (10\% fetal bovine serum, Glutamax (Invitrogen), antibiotics and non-essential amino acids). Cytospins of cell preparations were stained for $\mathrm{GH}$ and showed more than 95\% of GH-positive cells. Approximately 200000 cells were seeded for RT-PCR analysis and 20000 cells were put on $22 \mathrm{~mm}$ glass coverslips for $\left[\mathrm{Ca}^{2+}\right]_{\mathrm{i}}$ measurement. Cells were allowed to attach overnight, washed once with DMEM and checked for fibroblast contamination by phase-contrast microscopy. GH content of cell culture supernatant was determined (Immulite, Siemens, Erlangen, Germany) to assure the presence of GH-producing adenoma cells. Primary cell cultures were serum starved overnight before further experimental analyses.

\section{Measurement of intracellular free calcium $\left(\left[\mathrm{Ca}^{2+}\right]_{i}\right)$}

Cells cultured on coverslips for $48 \mathrm{~h}$ were loaded with $5 \mu \mathrm{M}$ Fura-2/AM (Invitrogen) and placed in a temperature-controlled superfusion chamber at $37^{\circ} \mathrm{C}$ perfused with buffer containing $20 \mathrm{mM}$ HEPES (pH 7.4), $130 \mathrm{mM} \mathrm{NaCl}, 4.7 \mathrm{mM} \mathrm{KCl}, 1.25 \mathrm{mM} \mathrm{CaCl}_{2}$, $1.2 \mathrm{mM} \mathrm{MgSO}_{4}, 1.2 \mathrm{mM} \mathrm{KH}{ }_{2} \mathrm{PO}_{4}, 10 \mathrm{mM}$ glucose and $0.1 \%$ BSA. $\left[\mathrm{Ca}^{2+}\right]_{\mathrm{i}}$ was recorded in single cells of average size and healthy appearance as described (39). Cells were treated for 2 min with superfusion buffer containing $45 \mathrm{mM} \mathrm{KCl}$ to cause membrane depolarisation and voltage-sensitive calcium influx and thereafter cells were allowed to re-equilibrate in superfusion buffer (see above) for $17 \mathrm{~min}$ (Supplementary Figure 1, see section on supplementary data given at the end of this article). Then an agonist selective for SSTR2, 3 and 5 (octreotide, Bachem, Bubendorf, Switzerland) or a pan-SSTR agonist (SRIF-14, Bachem) was administered for $3 \mathrm{~min}$ at a concentration of $100 \mathrm{nM}$ that causes full activation of the respective receptors to determine the effect on resting $\left[\mathrm{Ca}^{2+}\right]_{\mathrm{i}}$. Still in the presence of the respective SSTR agonist, a second 2-min stimulation with $45 \mathrm{mM} \mathrm{KCl}$ was performed to test the effect of SSTR activation on $\mathrm{Ca}^{2+}$ influx through voltage sensitive calcium channel (VSCC). Cells were considered as being responsive to the respective SSTR agonist if $\left[\mathrm{Ca}^{2+}\right]_{\mathrm{i}}$ decreased by at least $5 \mathrm{nM}$ upon treatment. For each adenoma sample, at least eight cells were analyzed. Cells that did not respond to $45 \mathrm{mM} \mathrm{KCl}$ with an increase in $\left[\mathrm{Ca}^{2+}\right]_{\mathrm{i}}$ were excluded.

\section{Quantitative RT-PCR and gsp genotyping}

Cells cultured for $48 \mathrm{~h}$ after isolation were treated with SRIF-14 (100 nM), octreotide (100 nM), forskolin (10 $\mathrm{MM}$, Calbiochem Merck, Darmstadt, Germany), H89 (10 $\mathrm{M}$, Calbiochem) or control medium for $8 \mathrm{~h}$. Total RNA was isolated (RNA-Gold, PeqLab, Erlangen, Germany) and reverse transcribed using anchored oligo-dT primers and superscript III reverse transcriptase (Invitrogen) along with RNA from the 19 normal anterior pituitary tissues. Quantitative RT-PCR analyses for glyceradehyde-3-phosphate-dehydrogenase $(G A P D H)$, the cAMP target gene-inducible cAMP early repressor (ICER), SSTR1 to SSTR5 and ZAC1 were based on previously described primers $(27,40,41)$ and were performed on a Roche Lightcycler 480 using Kapa-SYBR-Fast mixes (PeqLab). The primers for SSTR 5 do not detect recently described truncated SSTR5 variants $(32,33)$. Cp values were determined with the second-derivative maximum method (42). Individual adenoma samples were considered responsive when the mRNA levels in the treated sample showed at least a twofold suppression (ICER) or induction (ZAC1) compared with untreated controls. GSP mutation status was determined by PCR and direct sequencing of exons 7-10 of the GNAS1 gene.

\section{Statistical analyses}

The relative mRNA copy numbers per 100000 copies of GAPDH and the corresponding CI were calculated by the formula $2^{\left(\mathrm{Cp}_{\mathrm{GAPDH}}-\mathrm{Cp}_{\text {target gene }}\right)} \times 10^{5}$. Differences in $\left[\mathrm{Ca}^{2+}\right]_{\mathrm{i}}$ and mRNA levels were tested with paired or unpaired $t$-tests as appropriate using $\left[\mathrm{Ca}^{2+}\right]_{i}$ and $\mathrm{Cp}$ values that were normally distributed. Fisher's exact test was used to compare the proportions of granulation pattern, hormone expression GSP mutation status and immunohistochemical expression of SSTR. All statistical tests were performed in Sigma-Plot version 11. 


\section{Results}

\section{Immunohistochemical cytokeratin staining}

Twenty-one adenoma samples displayed a cytokeratin staining pattern characteristic for densely granulated somatotroph adenomas. Seven tumours showed distinct fibrous bodies and were classified as sparsely granulated variants. Twenty adenomas expressed GH only, whereas in five densely and in three sparsely granulated tumours, co-expression of prolactin could be demonstrated using immunohistochemistry (Table 1).

\section{cAMP signalling pathway}

Eighteen adenomas expressed wild-type GNAS1 sequence in the region examined. Ten of the 28 adenoma samples had a mutated GNAS1 gene. Eight adenomas harboured a R201C mutation and two a Q227L mutation (Table 2). Ten of the 21 densely granulated and none of the seven sparsely granulated adenomas had GSP mutations $(P=0.03)$ (Table 1$)$.

Activation status of the cAMP signalling pathway was assessed by measuring the expression of the cAMP target gene ICER, which is downstream of Gs $\alpha$, protein kinase A (PKA) and the cAMP-responsive element binding protein $(40,43)$. This approach integrates the activity of the cAMP signalling pathway at the transcriptional level and therefore in principle allows for the detection of yet unknown activating mechanisms of this pathway also distal to GSP mutations. The differences in the ICER expression between gsp-positive and GNAS1 wild-type adenomas were consistent with previously published results showing a higher basal

Table 1 Expression of GSP-mutated GNAS1, pituitary hormones and somatostatin receptor (SSTR) subtype in 21 densely and seven sparsely granulated $\mathrm{GH}-$ secreting adenomas. All adenomas were negative for SSTR4.

\begin{tabular}{|c|c|c|c|}
\hline \multirow[b]{2}{*}{ Parameters } & \multicolumn{2}{|c|}{ Cytokeratin staining pattern } & \multirow[b]{2}{*}{$P$ value } \\
\hline & $\begin{array}{c}\text { Densely } \\
\text { granulated (\%) } \\
n=21\end{array}$ & $\begin{array}{c}\text { Sparsely } \\
\text { granulated (\%) } \\
n=7\end{array}$ & \\
\hline GSP mutation & 48 & 0 & 0.030 \\
\hline \multicolumn{4}{|l|}{ Pituitary hormones } \\
\hline $\mathrm{GH}$ & 76 & 57 & 0.371 \\
\hline GH/PRL & 24 & 43 & \\
\hline \multicolumn{4}{|l|}{ SSTR1 } \\
\hline Cytoplasmic & 19 & 43 & 0.318 \\
\hline Membrane & 5 & 0 & 1.000 \\
\hline \multicolumn{4}{|l|}{ SSTR2 } \\
\hline Cytoplasmic & 67 & 0 & 0.006 \\
\hline Membrane & 86 & 0 & $<0.001$ \\
\hline \multicolumn{4}{|l|}{ SSTR3 } \\
\hline Cytoplasmic & 52 & 29 & 0.396 \\
\hline Membrane & 0 & 0 & 1.000 \\
\hline \multicolumn{4}{|l|}{ SSTR5 } \\
\hline Cytoplasmic & 0 & 57 & 0.002 \\
\hline Membrane & 0 & 29 & 0.056 \\
\hline
\end{tabular}

$P$ value was determined by Fisher's exact test. NS, not significant. but lower stimulated cAMP signalling pathway activity in gsp-positive adenomas (Supplementary Figure 2, see section on supplementary data given at the end of this article) (4).

In densely and sparsely granulated adenomas, basal ICER expression was similar (Fig. 1A). To further characterise the activation status of the cAMP signalling pathway, adenoma cells were treated with forskolin $(10 \mu \mathrm{M})$ or with the PKA inhibitor H89 $(10 \mu \mathrm{M})$. Forskolin $(10 \mu \mathrm{M})$ stimulated ICER expression in both densely and sparsely granulated adenomas about fourfold $(P<0.001)$ and treatment with H89 $(10 \mu \mathrm{M})$ significantly suppressed ICER expression compared with controls by about $70 \%(P<0.001)$ (Supplementary Figure 3, see section on supplementary data given at the end of this article). There were no differences in the effects of forskolin and H89 between the two adenoma subtypes indicating a similar degree of activation of the cAMP signalling pathway (Supplementary Figure 3).

Treatment for $8 \mathrm{~h}$ with either the pan-SSTR agonist SRIF-14 (100 nM), which activates all SSTR subtypes, or with the SSA octreotide (100 nM), which stimulates SSTR subtypes 2, 5 and to a lesser extent SSTR3, caused a marked decrease in ICER mRNA expression in the majority of tumour samples (Table 2) and significantly suppressed mean ICER levels $(P<0.001)$ (Fig. 1A). Both, SRIF-14 and octreotide were equally effective and there were no differences between densely and sparsely granulated adenomas (Fig. 1A).

\section{Calcium signalling pathway}

The average resting $\left[\mathrm{Ca}^{2+}\right]_{\mathrm{i}}$ in single cells obtained from 28 adenoma samples was $75 \mathrm{nM}(n=275$ cells from 28 adenoma cell preparations $(8-15$ cells per adenoma sample), 95\% CI 63-88 nM). Many cells showed spontaneous $\mathrm{Ca}^{2+}$ transients and $\mathrm{Ca}^{2+}$ oscillations with varying frequency and amplitude (Supplementary Figure 4, see section on supplementary data given at the end of this article). Upon treatment with octreotide $(100 \mathrm{nM})$, a decrease in $\left[\mathrm{Ca}^{2+}\right]_{\mathrm{i}}$ could be observed, which on average amounted to $27 \mathrm{nM}(n=105$ cells from 25 adenomas, 95\% CI $17-37 \mathrm{nM}$ ) and spontaneous $\mathrm{Ca}^{2+}$ transients and $\mathrm{Ca}^{2+}$ oscillations were suppressed (Fig. 1B, and Supplementary Figure 4). SRIF-14 (100 nM) caused a similar drop in $\left[\mathrm{Ca}^{2+}\right]_{\mathrm{i}}$, which was not significantly different from the effects of octreotide (Fig. 1B). As depicted in Table 2, most adenomas responded to octreotide and/or SRIF-14 (defined as a decrease in $\left[\mathrm{Ca}^{2+}\right]_{\mathrm{i}}$ by at least $5 \mathrm{nM}$ ). There were no differences observed between cells obtained from densely or sparsely granulated adenoma samples in the effects of octreotide or SRIF-14 on resting $\left[\mathrm{Ca}^{2+}\right]_{\mathrm{i}}$ (Fig. 1B).

Voltage-sensitive $\mathrm{Ca}^{2+}$ influx is an important component of resting and stimulus-induced $\mathrm{Ca}^{2+}$ signalling in somatotroph cells $(19,44)$. We therefore investigated the effect of octreotide or SRIF-14 on the $\mathrm{KCl}$ 

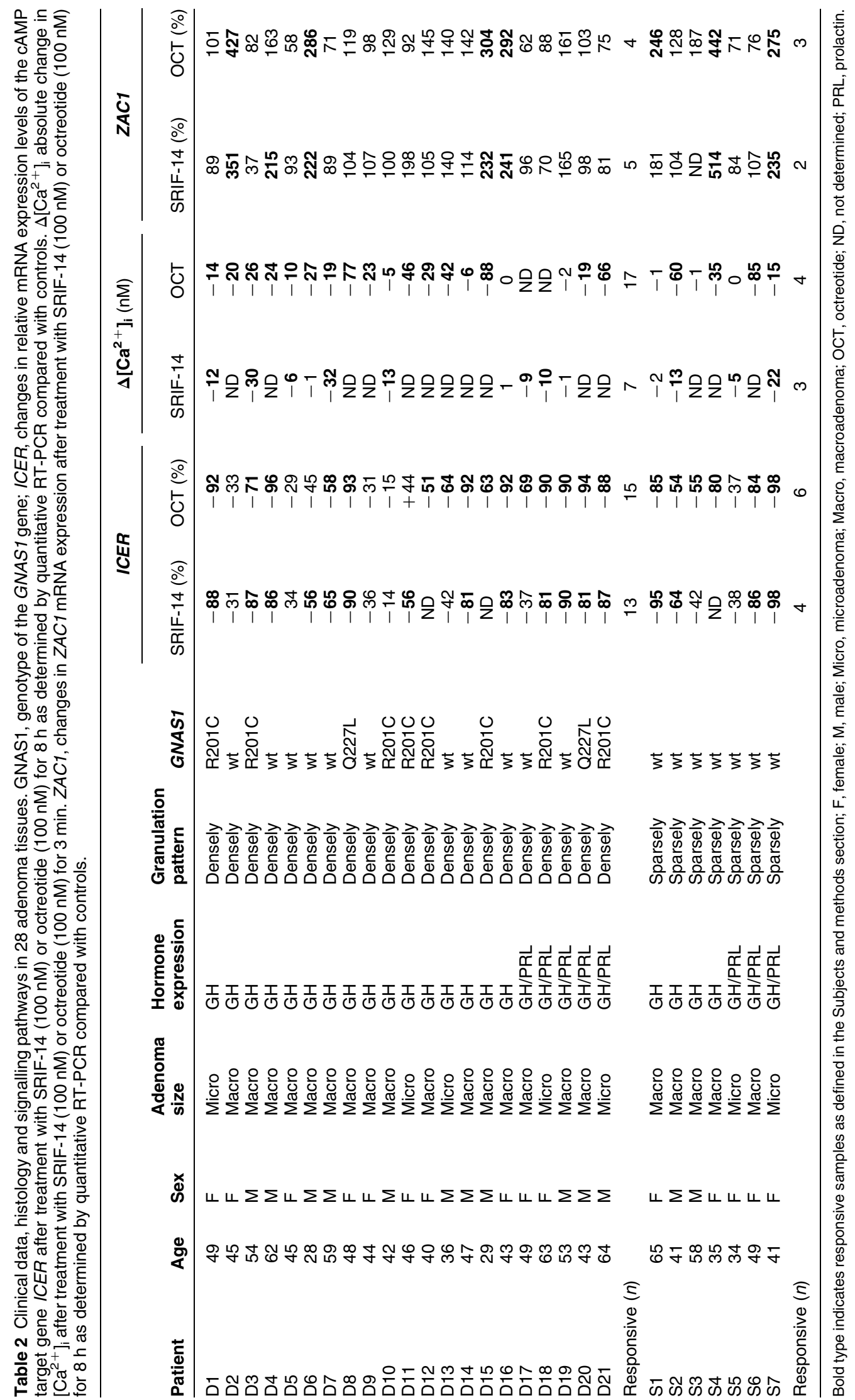


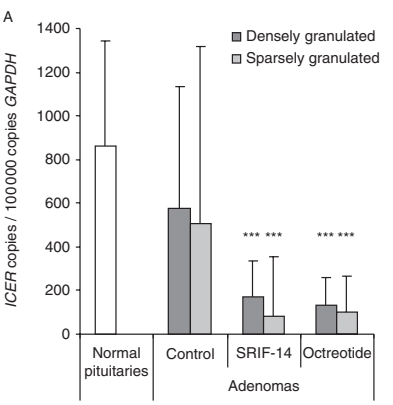

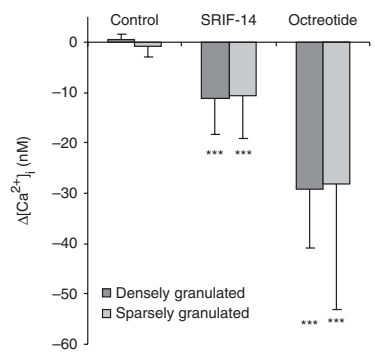

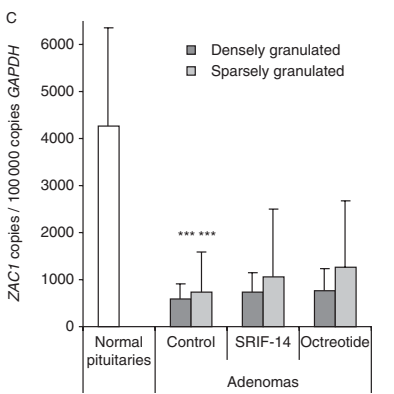

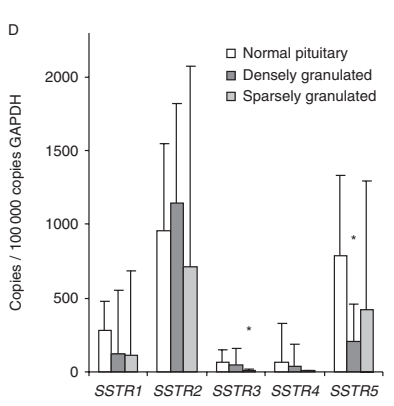

Figure 1 Signalling pathways and somatostatin receptors in 21 densely and seven sparsely granulated $\mathrm{GH}$-secreting adenoma cell preparations and 19 normal pituitaries. (A) cAMP signalling pathway: mRNA expression levels of the cAMP target gene ICER as determined by quantitative RT-PCR. Comparison between normal pituitaries, untreated adenoma samples (control) and samples treated with SRIF-14 (100 nM) or octreotide (100 nM) for $8 \mathrm{~h},{ }^{\star \star \star} P<0.001$ vs control. (B) Calcium signalling pathway: effect of SRIF-14 (100 nM) or octreotide (100 nM) on intracellular free calcium levels $\left(\left[\mathrm{Ca}^{2+}\right]_{\mathrm{i}}\right)$ (bars represent $20-104$ cells). ${ }^{\star \star \star} P<0.001$ vs control. (C) ZAC1 expression: ZAC1 mRNA levels as determined by quantitative RT-PCR. Comparison between normal pituitaries, untreated samples (control) and samples treated with SRIF-14 $(100 \mathrm{nM})$ or octreotide $(100 \mathrm{nM})$ for $8 \mathrm{~h},{ }^{* \star *} P<0.001 \mathrm{vs} \mathrm{normal}$ pituitaries. (D) SSTR subtype expression: levels of SSTR subtype mRNA as determined by quantitative RT-PCR. Comparison between normal pituitaries, densely and sparsely granulated adenomas. ${ }^{*} P<0.01$ vs normal pituitaries. All values are mean $\pm 95 \% \mathrm{Cl}$.

(45 mM)-induced rise in $\left[\mathrm{Ca}^{2+}\right]_{\mathrm{i}}$, which is caused by membrane depolarisation with consecutive activation of $\mathrm{Ca}^{2+}$ influx through VSCC (18). $\mathrm{KCl}(45 \mathrm{mM})$ increased $\left[\mathrm{Ca}^{2+}\right]_{\mathrm{i}}$ by $34 \mathrm{nM}(n=275$ cells from 28 adenoma cell preparations, 95\% CI 22-46 nM). Pretreatment for 3 min with octreotide $(100 \mathrm{nM}, n=105$ cells from 25 adenomas) or SRIF-14 (100 nM, $n=51$ cells from 15 adenoma preparations) had no effect on the $\mathrm{KCl}$ (45 mM)-induced peak rise in $\left[\mathrm{Ca}^{2+}\right]_{\mathrm{i}}$ compared with vehicle-treated control cells neither in cells obtained from densely nor from sparsely granulated adenomas (Supplementary Figure 5, see section on supplementary data given at the end of this article). Thus, the inhibition of resting $\left[\mathrm{Ca}^{2+}\right]_{\mathrm{i}}$ by SSTR activation in somatotroph adenoma cells does not appear to be caused by a direct inhibitory action on voltage-sensitive $\mathrm{Ca}^{2+}$ influx. SSTR-induced suppression, however, of cytosolic calcium signalling might occur indirectly by the inhibition of the cAMP signalling pathway whose activation has been shown to promote voltage-sensitive $\mathrm{Ca}^{2+}$ influx in pituitary cells $(18,19,44)$.

\section{ZAC1 expression and modulation by SSTR agonists}

ZAC1 expression was detectable by quantitative RT-PCR in all tumour samples. The mean expression level of ZAC1 in the $28 \mathrm{GH}$-secreting adenomas (631 copies/100 000 copies GAPDH, 95\% CI 438-909 copies) was significantly lower than in the 19 normal pituitaries (4262 copies/100 000 copies GAPDH, 95\% CI 2856-6360 copies) $(P<0.001)$ (Fig. 1C). There was no significant difference between the ZAC1 levels in densely and sparsely granulated somatotroph adenomas.

Treatment with octreotide $(100 \mathrm{nM})$ or SRIF-14 $(100 \mathrm{nM})$ for $8 \mathrm{~h}$ resulted in an average 1.25 -fold increase in ZAC1 expression levels $(n=28$ adenoma, $P<0.05)$. However, when analysing densely and sparsely granulated adenomas separately, the octreotide- or SRIF-induced changes in ZAC1 expression were no longer significant, and there were no obvious differences between the two groups (Fig. 1C). This might be explained by the high variability of the responses with less than half of the adenoma samples demonstrating a rise in ZAC1 expression (defined as a more than twofold increase in ZAC1 mRNA levels) in response to SSTR activation (Table 2).

\section{Expression of SSTR subtypes}

SSTR2 mRNA was the most abundant subtype in adenomas according to quantitative RT-PCR analysis (Fig. 1D). SSTR2 mRNA levels in both densely and sparsely adenomas were not different from those in normal pituitaries (Fig. 1D). Immunohistochemistry, however, revealed that protein expression of SSTR 2 was restricted to densely granulated adenomas, both for membrane (86 vs $0 \% ; P<0.001$ ) and for cytoplasmic localisation ( 67 vs $0 \% ; P=0.006$ ) (Table 1 ).

SSTR 5 mRNA was the second most abundant SSTR subtype expressed in adenomas. Densely but not sparsely granulated tumours had significantly lower SSTR 5 mRNA levels than normal pituitaries $(P<0.01)$ (Fig. 1D). In the immunohistochemical analysis, membrane and cytoplasmic expression of SSTR 5 protein was exclusively observed in the sparsely granulated adenoma cells (29 vs $0 \% ; P=0.056$ and 57 vs $0 \% ; P=0.002$ ) (Table 1 ).

The expression of mRNA for SSTR 1, 3 and 4 was clearly lower than that for SSTR2 and 5 (Fig. 1D). Immunohistochemical membrane staining for these subtypes was also rare or absent, but cytoplasmic staining for SSTR1 and 3 was frequently detected in both adenoma subtypes, with no difference between them (Table 1). SSTR4 protein could not be detected by 
immunohistochemistry, which is consistent with previous reports (45).

Detection of SSTR mRNA was compared with SSTR immunohistochemical protein staining, which revealed concordance rates between 57 and 89\% comparable to published results from various other tissues $(46,47,48)$ (Supplementary Table 3, see section on supplementary data given at the end of this article).

\section{Discussion}

The main goal in the molecular characterisation of benign and malignant neoplasms is to unravel the mechanisms underlying the abnormal growth behaviour and to identify targets to stop or retard enhanced cell proliferation. In addition, in the treatment of endocrine neoplasm such as acromegaly, the control of excess hormone secretion is another important goal. Fortunately, there are often physiological mechanisms that can be exploited to develop therapeutic strategies to inhibit abnormal hormone secretion, such as the inhibition of GH secretion by administration of SSA. The pathophysiology, however, behind the development, abnormal growth and function of somatotropinomas is less well understood.

Somatotropinomas can be subclassified into a densely and a sparsely granulated phenotype (8). There appear to be functional differences between the two subtypes as densely granulated adenomas respond better to medical treatment with currently available SSA than the sparsely granulated variant $(9,10,11,12,13)$. The two GH-producing adenoma subtypes can be easily distinguished using antibodies against cytokeratins $(7,8)$. Cytokeratins are the building blocks of the cytoplasmic intermediate filaments, which are structural components of the cell that provide mechanical stability. There is some evidence that intermediate filaments may have a role in exocytosis and secretion but their role in cellular signalling and function is largely unknown (49). Thus, the histomorphological phenotypes may be associated with distinct molecular properties leading to distinct clinical characteristics.

We found no differences in the cAMP or cytosolic $\mathrm{Ca}^{2+}$ signalling pathways between densely and sparsely granulated GH-secreting adenoma cells. Pharmacological stimulation of SSTR either by the pan-agonist SRIF-14 or by octreotide inhibited the cAMP pathway or suppressed the cytosolic $\mathrm{Ca}^{2+}$ levels in most adenoma cells irrespective of their granulation pattern. The expression of the transcription factor ZAC1, which negatively regulates somatotroph growth and function (26) and that has been suggested as one pathophysiological factor in the development of GH-secreting adenomas, was significantly lower in the adenoma cells compared with normal pituitary tissue, which is consistent with previous reports $(27,28)$. Furthermore, we could demonstrate for the first time in human somatotroph adenomas that SSTR activation can up-regulate ZAC1 expression as has been reported before for rat $\mathrm{GH} 3$ cells (26). The overall up-regulation of ZAC1 by SSTR activation, however, was rather small with a high variability in the stimulation of ZAC1 expression between individual adenoma preparations. The precise role of ZAC1 in SSTR agonist control of growth and hormone secretion of somatotroph adenomas remains to be defined. There were no differences in basal or SSTR-stimulated ZAC1 expression between densely and sparsely granulated adenoma cells. Together, our studies provide no evidence for an impact of the cytokeratin staining pattern on the investigated intracellular signalling mechanisms that are known to be central to somatotroph cell regulation.

All tissues were responsive to pharmacological stimulation of SSTRs in at least one of the tested pathways and 21 of the 28 samples were responsive in at least two of the three pathways. This indicates that most GH-producing adenomas could be amenable to SSTR-based treatment as long as the agonist used reaches a high-enough concentration in vivo to efficiently stimulate the SSTR subtypes that are expressed on the respective adenoma.

In vitro studies indicate that most biological effects of SSA in GH-producing cells are mediated by SSTR 2 and SSTR $5(50,51)$. To test whether this also holds true for densely and sparsely granulated adenomas, we compared the effects of SRIF-14, which activates all five SSTR subtypes, with the effects of octreotide (100 nM) that activates SSTR subtypes 2 and 5 and to a lesser extent SSTR3 at this concentration (52). There were no differences in the actions of SRIF-14 and octreotide and no differences between densely and sparsely granulated adenomas. As the expression of SSTR2 and SSTR5 was most abundant both at the mRNA and at the protein level, it appears most likely that the observed effects of SRIF-14 and octreotide were mainly through activation of SSTR subtype 2 and/or 5 . This is in line with previous studies showing that SSTR subtypes 1 and 4 are not required for the inhibitory effects of somatostatin on somatotroph adenoma cells $(50,51)$ and applies to both densely and sparsely granulated somatotroph adenomas.

While there were no differences in the tested pathways and their regulation by SSTR stimulation, there was, however, a significant difference in the pattern of SSTR subtype expression between densely and sparsely granulated adenomas. By immunohistochemistry, SSTR2 protein was exclusively observed in densely granulated tumours whereas sparsely granulated ones exclusively expressed SSTR 5. In densely but not in sparsely granulated tumours, SSTR 5 mRNA levels were significantly lower compared with normal pituitaries, while for SSTR 2 mRNA, no differences could be observed. Overall SSTR mRNA expression profiles corresponded well but not perfectly to protein expression, probably because mRNA expression may not always lead to translation into detectable protein 
expression. (46, 47, 48). Therefore, determining protein expression by immunohistochemistry appears to be the preferable measure for defining the adenoma cell SSTR status.

Whether there is a causal relationship between the patterns of SSTR subtype expression and the GH secretory granulation pattern or vice versa remains an open question. Although we observed no differences in the SSTR-induced actions on the tested pathways between the two adenoma subtypes, this does not preclude that SSTR2 and SSTR5 may differentially regulate other intracellular signals that determine the pattern of $\mathrm{GH}$-containing secretory granules. Recently described truncated SSTR 5 variants have been described with different signalling behaviour compared with fulllength SSTR5 and further expand the spectrum of possible regulatory interactions $(32,33)$. The SSTR 5 antibody used in this study was raised against the C-terminus of SSTR5, which is not present in these truncated SSTR 5 variants. Further studies are therefore required to evaluate the impact of these SSTR 5 variants on signalling, differentiation and therapeutic response in pituitary GH-secreting adenomas and their subtypes.

Clinical studies have shown a correlation of the expression of SSTR2 with patients' responses to treatment with SSA like octreotide or lanreotide that reach serum concentrations that effectively stimulate SSTR2 but only modestly activate $\operatorname{SSTR} 5(34,52,53$, $54,55,56,57)$. As shown in this study and by others' (13), densely granulated adenomas predominantly express SSTR2, which explains the clinical observation that densely granulated adenomas respond better than sparsely granulated ones to treatment with the currently available SSA octreotide or lanreotide $(9,10,11,12,13)$.

To overcome the narrow SSTR spectrum activated by octreotide or lanreotide in vivo, novel SSA with enhanced affinity to SSTR 5 have been developed and one of them has been recently proven to be an effective clinical treatment option $(58,59,60)$. As most adenomas in our study responded to pharmacological SSTR stimulation at the molecular level in vitro, we would speculate that patients with sparsely granulated somatotropinomas, which lack SSTR2 but express the SSTR 5 subtype, might benefit from treatment with novel SSA that have a higher affinity to SSTR5 (60). Whether this is the case remains to be proven in clinical studies correlating the therapeutic response to these compounds with the histomorphological phenotype and SSTR subtype expression pattern.

\section{Supplementary data}

This is linked to the online version of the paper at http://dx.doi.org/ 10.1530/EJE-13-0134.

\section{Declaration of interest}

B Mayr, R Buslei and M Theodoropoulou have nothing to declare.

\section{Funding}

G K Stalla, M Buchfelder and C Schöfl have received grant support and speakers, honoraria from Pfizer (Berlin, Germany) and Novartis. This study was supported by an unconditional grant from Pfizer (Berlin, Germany) to C Schöfl.

\section{References}

1 Asa SL \& Ezzat S. The pathogenesis of pituitary tumours. Nature Reviews. Cancer 20022 836-849. (doi:10.1038/nrc926)

2 Drange MR \& Melmed S. Molecular pathogenesis of acromegaly. Pituitary 19992 43-50. (doi:10.1023/A:1009917920589)

3 Karhu A \& Aaltonen LA. Susceptibility to pituitary neoplasia related to MEN-1, CDKN1B and AIP mutations: an update. Human Molecular Genetics 200716 R73-R79. (doi:10.1093/ $\mathrm{hmg} / \mathrm{ddm} 036$ )

4 Landis CA, Masters SB, Spada A, Pace AM, Bourne HR \& Vallar L. GTPase inhibiting mutations activate the $\alpha$ chain of Gs and stimulate adenylyl cyclase in human pituitary tumours. Nature 1989340 692-696. (doi:10.1038/340692a0)

5 Vierimaa O, Georgitsi M, Lehtonen R, Vahteristo P, Kokko A, Raitila A, Tuppurainen K, Ebeling TM, Salmela PI, Paschke R et al. Pituitary adenoma predisposition caused by germline mutations in the AIP gene. Science 2006312 1228-1230. (doi:10.1126/ science.1126100)

6 Leontiou CA, Gueorguiev M, van der Spuy J, Quinton R, Lolli F, Hassan S, Chahal HS, Igreja SC, Jordan S, Rowe J et al. The role of the aryl hydrocarbon receptor-interacting protein gene in familial and sporadic pituitary adenomas. Journal of Clinical Endocrinology and Metabolism 200893 2390-2401. (doi:10.1210/ jc.2007-2611)

7 Horvath E \& Kovacs K. Pathology of acromegaly. Neuroendocrinology 200683 161-165. (doi:10.1159/000095524)

8 Obari A, Sano T, Ohyama K, Kudo E, Qian ZR, Yoneda A, Rayhan N, Mustafizur Rahman M \& Yamada S. Clinicopathological features of growth hormone-producing pituitary adenomas: difference among various types defined by cytokeratin distribution pattern including a transitional form. Endocrine Pathology 2008 19 82-91. (doi:10.1007/s12022-008-9029-z)

9 Bakhtiar Y, Hirano H, Arita K, Yunoue S, Fujio S, Tominaga A, Sakoguchi T, Sugiyama K, Kurisu K, Yasufuku-Takano J et al. Relationship between cytokeratin staining patterns and clinicopathological features in somatotropinomae. European Journal of Endocrinology 2010163 531-539. (doi:10.1530/EJE-10-0586)

10 Bhayana S, Booth GL, Asa SL, Kovacs K \& Ezzat S. The implication of somatotroph adenoma phenotype to somatostatin analog responsiveness in acromegaly. Journal of Clinical Endocrinology and Metabolism 200590 6290-6295. (doi:10.1210/jc.20050998)

11 Fougner SL, Casar-Borota O, Heck A, Berg JP \& Bollerslev J. Adenoma granulation pattern correlates with clinical variables and effect of somatostatin analogue treatment in a large series of patients with acromegaly. Clinical Endocrinology 2012 76 96-102. (doi:10.1111/j.1365-2265.2011.04163.x)

12 Larkin S, Reddy R, Karavitaki N, Cudlip S, Wass J \& Ansorge O. Granulation pattern, but not GSP or GHR mutation, is associated with clinical characteristics in somatostatin-naive patients with somatotroph adenomas. European Journal of Endocrinology 2013 168 491-499. (doi:10.1530/EJE-12-0864)

13 Brzana J, Yedinak CG, Gultekin SH, Delashaw JB \& Fleseriu M. Growth hormone granulation pattern and somatostatin receptor subtype $2 \mathrm{~A}$ correlate with postoperative somatostatin receptor ligand response in acromegaly: a large single center experience. Pituitary 2013. In press. (doi:10.1007/s11102-012-0445-1)

14 Lania A, Mantovani G, Ferrante E, Zavanone LM, Locatelli M, Corbetta S, Beck-Peccoz P \& Spada A. Gonadotropin-releasing 
hormone initiates multiple signaling pathways in human GH-secreting adenomas. Journal of Endocrinological Investigation 200427 328-333.

15 Boikos SA \& Stratakis CA. Molecular genetics of the cAMPdependent protein kinase pathway and of sporadic pituitary tumorigenesis. Human Molecular Genetics 200716 R80-R87. (doi:10.1093/hmg/ddm019)

16 Sato T, Nakamura Y, Shiimura Y, Ohgusu H, Kangawa K \& Kojima M. Structure, regulation and function of ghrelin. Journal of Biochemistry 2012151 119-128. (doi:10.1093/jb/mvr134)

17 Lim CT, Kola B \& Korbonits M. The ghrelin/GOAT/GHS-R system and energy metabolism. Reviews in Endocrine $\&$ Metabolic Disorders 201112 173-186. (doi:10.1007/s11154-011-9169-1)

18 Meier K, Knepel W \& Schöfl C. Potassium depolarization elevates cytosolic free calcium concentration in rat anterior pituitary cells through 1,4-dihydropyridine-sensitive, omega-conotoxin-insensitive calcium channels. Endocrinology 1988122 2764-2770. (doi:10.1210/endo-122-6-2764)

19 Schöfl C, Sandow J \& Knepel W. GRF elevates cytosolic free calcium concentration in rat anterior pituitary cells. American Journal of Physiology 1987253 E591-E594.

20 Garcia A, Alvarez CV, Smith RG \& Dieguez C. Regulation of Pit-1 expression by ghrelin and GHRP-6 through the GH secretagogue receptor. Molecular Endocrinology 200115 1484-1495. (doi:10. 1210/me.15.9.1484)

21 Yamashita N, Shibuya N \& Ogata E. Hyperpolarization of the membrane potential caused by somatostatin in dissociated human pituitary adenoma cells that secrete growth hormone. PNAS 1986 83 6198-6202. (doi:10.1073/pnas.83.16.6198)

22 Yasufuku-Takano J, Takano K, Takei T, Fukumoto S, Teramoto A, Takakura K, Yamashita N \& Fujita T. Heterozygous gsp mutation renders ion channels of human somatotroph adenoma cells unresponsive to growth hormone-releasing hormone. Endocrinology 1999140 2018-2026. (doi:10.1210/en.140.5.2018)

23 Bilezikjian LM \& Vale WW. Stimulation of adenosine 3',5'monophosphate production by growth hormone-releasing factor and its inhibition by somatostatin in anterior pituitary cells in vitro. Endocrinology 1983113 1726-1731. (doi:10.1210/ endo-113-5-1726)

24 Spada A, Reza-Elahi F, Lania A, Gil-del-Alamo P, Bassetti M \& Faglia G. Hypothalamic peptides modulate cytosolic free $\mathrm{Ca}^{2+}$ levels and adenylyl cyclase activity in human nonfunctioning pituitary adenomas. Journal of Clinical Endocrinology and Metabolism 199173 913-918. (doi:10.1210/jcem-73-4-913)

25 Chen ZP, Xu S, Lightman SL, Hall L \& Levy A. Intracellular calcium ion responses to somatostatin in cells from human somatotroph adenomas. Clinical Endocrinology 199746 45-53. (doi:10.1046/ j.1365-2265.1997.d01-1739.x)

26 Theodoropoulou M, Zhang J, Laupheimer S, Paez-Pereda M, Erneux C, Florio T, Pagotto U \& Stalla GK. Octreotide, a somatostatin analogue, mediates its antiproliferative action in pituitary tumor cells by altering phosphatidylinositol 3-kinase signaling and inducing Zac1 expression. Cancer Research $2006 \mathbf{6 6}$ 1576-1582. (doi:10.1158/0008-5472.CAN-05-1189)

27 Pagotto U, Arzberger T, Theodoropoulou M, Grübler Y, Pantaloni C, Saeger W, Losa M, Journot L, Stalla GK \& Spengler D. The expression of the antiproliferative gene ZAC is lost or highly reduced in nonfunctioning pituitary adenomas. Cancer Research $2000606794-6799$.

28 Theodoropoulou M, Stalla GK \& Spengler D. ZAC1 target genes and pituitary tumorigenesis. Molecular and Cellular Endocrinology 2010326 60-65. (doi:10.1016/j.mce.2010.01.033)

29 Buslei R, Hölsken A, Hofmann B, Kreutzer J, Siebzehnrübl F, Hans V, Oppel F, Buchfelder M, Fahlbusch R \& Blümcke I. Nuclear $\beta$-catenin accumulation associates with epithelial morphogenesis in craniopharyngiomas. Acta Neuropathologica $2007 \quad 113$ 585-590. (doi:10.1007/s00401-006-0184-3)

30 Parry JJ, Chen R, Andrews R, Lears KA \& Rogers BE. Identification of critical residues involved in ligand binding and $G$ protein signaling in human somatostatin receptor subtype 2 . Endocrinology 2012153 2747-2755. (doi:10.1210/en.2011-1662)
31 Schmid HA, Lambertini C, van Vugt HH, Barzaghi-Rinaudo P, Schäfer J, Hillenbrand R, Sailer AW, Kaufmann M \& Nuciforo P. Monoclonal antibodies against the human somatostatin receptor subtypes 1-5: development and immunohistochemical application in neuroendocrine tumors. Neuroendocrinology 201295 232-247. (doi:10.1159/000330616)

32 Cordoba-Chacon J, Gahete MD, Duran-Prado M, Luque RM \& Castano JP. Truncated somatostatin receptors as new players in somatostatin-cortistatin pathophysiology. Annals of the New York Academy of Sciences $2011 \mathbf{1 2 2 0} 6-15$. (doi:10.1111/j.17496632.2011.05985.x)

33 Duran-Prado M, Gahete MD, Hergueta-Redondo M, MartinezFuentes AJ, Cordoba-Chacon J, Palacios J, Gracia-Navarro F, Moreno-Bueno G, Malagon MM, Luque RM et al. The new truncated somatostatin receptor variant sst5TMD4 is associated to poor prognosis in breast cancer and increases malignancy in MCF-7 cells. Oncogene 201231 2049-2061. (doi:10.1038/onc. 2011.389)

34 Plöckinger U, Albrecht S, Mawrin C, Saeger W, Buchfelder M, Petersenn S \& Schulz S. Selective loss of somatostatin receptor 2 in octreotide-resistant growth hormone-secreting adenomas. Journal of Clinical Endocrinology and Metabolism 200893 1203-1210. (doi:10.1210/jc.2007-1986)

35 Kulaksiz H, Eissele R, Rössler D, Schulz S, Höllt V, Cetin Y \& Arnold R. Identification of somatostatin receptor subtypes 1, 2A, 3 , and 5 in neuroendocrine tumours with subtype specific antibodies. Gut 200250 52-60. (doi:10.1136/gut.50.1.52)

36 Kumar U, Sasi R, Suresh S, Patel A, Thangaraju M, Metrakos P, Patel SC \& Patel YC. Subtype-selective expression of the five somatostatin receptors (hSSTR1-5) in human pancreatic islet cells: a quantitative double-label immunohistochemical analysis. Diabetes 199948 77-85. (doi:10.2337/diabetes.48.1.77)

37 Volante M, Brizzi MP, Faggiano A, La Rosa S, Rapa I, Ferrero A, Mansueto G, Righi L, Garancini S, Capella C et al. Somatostatin receptor type $2 \mathrm{~A}$ immunohistochemistry in neuroendocrine tumors: a proposal of scoring system correlated with somatostatin receptor scintigraphy. Modern Pathology $2007201172-1182$. (doi:10.1038/modpathol.3800954)

38 Unger N, Serdiuk I, Sheu SY, Walz MK, Schulz S, Saeger W, Schmid KW, Mann K \& Petersenn S. Immunohistochemical localization of somatostatin receptor subtypes in benign and malignant adrenal tumours. Clinical Endocrinology 200868 850857. (doi:10.1111/j.1365-2265.2007.03124.x)

39 Rus R, Haag C, Bumke-Vogt C, Bähr V, Mayr B, Möhlig M, Schulze E, Frank-Raue K, Raue F \& Schöfl C. Novel inactivating mutations of the calcium-sensing receptor: the calcimimetic NPS R-568 improves signal transduction of mutant receptors. Journal of Clinical Endocrinology and Metabolism $2008 \mathbf{9 3} 4797-4803$. (doi:10.1210/jc.2008-1076)

40 Mayr BM, Canettieri G \& Montminy MR. Distinct effects of cAMP and mitogenic signals on CREB-binding protein recruitment impart specificity to target gene activation via CREB. PNAS 200198 10936-10941. (doi:10.1073/pnas.191152098)

41 Taboada GF, Luque RM, Bastos W, Guimaraes RF, Marcondes JB, Chimelli LM, Fontes R, Mata PJ, Filho PN, Carvalho DP et al. Quantitative analysis of somatostatin receptor subtype (SSTR1-5) gene expression levels in somatotropinomas and non-functioning pituitary adenomas. European Journal of Endocrinology $2007 \mathbf{1 5 6}$ 65-74. (doi:10.1530/eje.1.02313)

42 Tichopad A, Dilger M, Schwarz G \& Pfaffl MW. Standardized determination of real-time PCR efficiency from a single reaction set-up. Nucleic Acids Research 200331 e122. (doi:10.1093/nar/ gng122)

43 Mayr B \& Montminy M. Transcriptional regulation by the phosphorylation-dependent factor CREB. Nature Reviews. Molecular Cell Biology 2001 2 599-609. (doi:10.1038/35085068)

44 Holl RW, Thorner MO, Mandell GL, Sullivan JA, Sinha YN \& Leong DA. Spontaneous oscillations of intracellular calcium and growth hormone secretion. Journal of Biological Chemistry 1988 $2639682-9685$. 
45 Miller GM, Alexander JM, Bikkal HA, Katznelson L, Zervas NT \& Klibanski A. Somatostatin receptor subtype gene expression in pituitary adenomas. Journal of Clinical Endocrinology and Metabolism 1995 80 1386-1392. (doi:10.1210/jc.80.4.1386)

46 Pisarek H, Krupinski R, Kubiak R, Borkowska E, Pawlikowski M \& Winczyk K. Differential expression of somatostatin receptor subtype-related genes and proteins in non-functioning and functioning adrenal cortex adenomas. Molecular Medicine Reports 20114 963-969.

47 Kumar U, Grigorakis SI, Watt HL, Sasi R, Snell L, Watson P \& Chaudhari S. Somatostatin receptors in primary human breast cancer: quantitative analysis of mRNA for subtypes 1-5 and correlation with receptor protein expression and tumor pathology. Breast Cancer Research and Treatment 200592 175-186. (doi:10.1007/s10549-005-2414-0)

48 Pisarek H, Stepien T, Kubiak R, Borkowska E \& Pawlikowski M. Expression of somatostatin receptor subtypes in human thyroid tumors: the immunohistochemical and molecular biology (RT-PCR) investigation. Thyroid Research 20092 1. (doi:10.1186/ 1756-6614-2-1)

49 Oriolo AS, Wald FA, Ramsauer VP \& Salas PJ. Intermediate filaments: a role in epithelial polarity. Experimental Cell Research 2007313 2255-2264. (doi:10.1016/j.yexcr.2007.02.030)

50 Shimon I, Taylor JE, Dong JZ, Bitonte RA, Kim S, Morgan B, Coy DH, Culler MD \& Melmed S. Somatostatin receptor subtype specificity in human fetal pituitary cultures. Differential role of SSTR2 and SSTR 5 for growth hormone, thyroid-stimulating hormone, and prolactin regulation. Journal of Clinical Investigation 199799 789-798. (doi:10.1172/JCI119225)

51 Shimon I, Yan X, Taylor JE, Weiss MH, Culler MD \& Melmed S. Somatostatin receptor (SSTR) subtype-selective analogues differentially suppress in vitro growth hormone and prolactin in human pituitary adenomas. Novel potential therapy for functional pituitary tumors. Journal of Clinical Investigation $1997 \mathbf{1 0 0}$ 2386-2392. (doi:10.1172/JCI119779)

52 Olias G, Viollet C, Kusserow H, Epelbaum J \& Meyerhof W. Regulation and function of somatostatin receptors. Journal of Neurochemistry 200489 1057-1091. (doi:10.1111/j.14714159.2004.02402.x)

53 Barlier A, Pellegrini-Bouiller I, Gunz G, Zamora AJ, Jaquet P \& Enjalbert A. Impact of gsp oncogene on the expression of genes coding for Gs $\alpha$, Pit-1, Gi2 $\alpha$, and somatostatin receptor 2 in human somatotroph adenomas: involvement in octreotide sensitivity. Journal of Clinical Endocrinology and Metabolism $1999 \mathbf{8 4}$ 2759-2765. (doi:10.1210/jc.84.8.2759)

54 Jaquet P, Saveanu A, Gunz G, Fina F, Zamora AJ, Grino M, Culler MD, Moreau JP, Enjalbert A \& Ouafik LH. Human somatostatin receptor subtypes in acromegaly: distinct patterns of messenger ribonucleic acid expression and hormone suppression identify different tumoral phenotypes. Journal of Clinical Endocrinology and Metabolism 200085 781-792. (doi:10.1210/ jc. 85.2 .781$)$

55 Ferone D, de Herder WW, Pivonello R, Kros JM, van Koetsveld PM, de Jong T, Minuto F, Colao A, Lamberts SW \& Hofland LJ. Correlation of in vitro and in vivo somatotropic adenoma responsiveness to somatostatin analogs and dopamine agonists with immunohistochemical evaluation of somatostatin and dopamine receptors and electron microscopy. Journal of Clinical Endocrinology and Metabolism 200893 1412-1417. (doi:10.1210/ jc. 2007-1358)

56 Fougner SL, Borota OC, Berg JP, Hald JK, Ramm-Pettersen J \& Bollerslev J. The clinical response to somatostatin analogues in acromegaly correlates to the somatostatin receptor subtype $2 \mathrm{a}$ protein expression of the adenoma. Clinical Endocrinology 200868 458-465. (doi:10.1111/j.1365-2265.2007.03065.x)

57 Lancranjan I, Bruns C, Grass P, Jaquet P, Jervell J, Kendall-Taylor P, Lamberts SWJ, Marbach P, Ørskov H, Pagani G et al. Sandostatin LAR ${ }^{\circledR}$ : pharmacokinetics, pharmacodynamics, efficacy, and tolerability in acromegalic patients. Metabolism 199544 (Suppl 1) 18-26. (doi:10.1016/0026-0495(95)90306-2)

58 Petersenn S, Farrall AJ, Block C, Melmed S, Schopohl J, Caron P, Cuneo R, Kleinberg D, Colao A, Ruffin M et al. Long-term efficacy and safety of subcutaneous pasireotide in acromegaly: results from an open-ended, multicenter, phase II extension study. Pituitary 2013. In press. (doi:10.1007/s11102-013-0478-0)

59 Petersenn S, Schopohl J. Barkan A, Mohideen P, Colao A, Abs R, Buchelt A, Ho YY, Hu K, Farrall AJ et al. Pasireotide (SOM230) demonstrates efficacy and safety in patients with acromegaly: a randomized, multicenter, phase II trial. Journal of Clinical Endocrinology and Metabolism 201095 2781-2789. (doi:10. 1210/jc.2009-2272)

60 Hofland LJ, van der Hoek J, van Koetsveld PM, de Herder WW, Waaijers M, Sprij-Mooij D, Bruns C, Weckbecker G, Feelders R, van der Lely AJ et al. The novel somatostatin analog SOM230 is a potent inhibitor of hormone release by growth hormoneand prolactin-secreting pituitary adenomas in vitro. Journal of Clinical Endocrinology and Metabolism 200489 1577-1585. (doi:10.1210/jc.2003-031344)

Received 14 February 2013

Revised version received 11 June 2013

Accepted 11 July 2013 